\title{
Simulating the effects of different potassium and water supply regimes on soil water content and water table depth over a rotation of a tropical Eucalyptus grandis plantation ${ }^{\text {is }}$
}

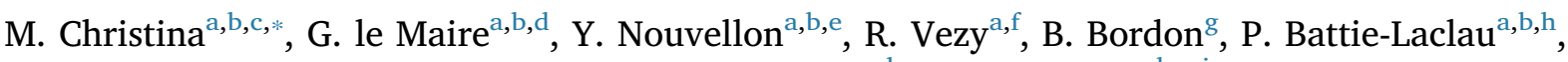 \\ J.L.M. Gonçalves ${ }^{g}$, J.S. Delgado-Rojas ${ }^{g}$, J.-P. Bouillet ${ }^{\mathrm{a}, \mathrm{b}, g}$, J.-P. Laclau ${ }^{\mathrm{a}, \mathrm{b}, \mathrm{g}, \mathrm{i}}$ \\ a CIRAD, UMR Eco\&Sols, F-34398 Montpellier, France \\ ${ }^{\mathrm{b}}$ Eco\&Sols, Univ Montpellier, CIRAD, INRA, IRD, Montpellier SupAgro, Montpellier, France \\ ${ }^{\mathrm{c}}$ CIRAD, UR 115 AIDA, F-34398 Montpellier, France \\ d NIPE, UNICAMP, CEP 13083-970 Campinas, SP, Brazil \\ e Universidade de São Paulo, Departamento de Ciencias Atmosfericas, CEP 05508-900 São Paulo, SP, Brazil \\ f INRA, UMR 1391 ISPA, F-33140 Villenave d'Ornon, France \\ ${ }^{g}$ Universidade de São Paulo, ESALQ, CEP 13418-900 Piracicaba, SP, Brazil \\ ${ }^{\text {h }}$ Universidade de São Paulo, CENA, CEP 13400-970 Piracicaba, SP, Brazil \\ ' Universidade Estadual Paulista 'Júlio de Mesquita Filho', Departamento de Solos e Recursos Ambientais, CEP 18610-300 Botucatu, SP, Brazil
}

\section{A R T I C L E I N F O}

\section{Keywords:}

Water resources

Groundwater

Brazil

Eucalyptus

Deep roots

Nutrients

\begin{abstract}
A B S T R A C T
Although large amounts of potassium (K) are applied in tropical crops and planted forests, little is known about the interaction between $\mathrm{K}$ nutrition and water supply regimes on water resources in tropical regions. This interaction is a major issue because climate change is expected to increase the length of drought periods in many tropical regions and soil water availability in deep soil layers is likely to have a major influence on tree growth during dry periods in tropical planted forests. A process-based model (MAESPA) was parameterized in a throughfall exclusion experiment in Brazil to gain insight into the combined effects of $\mathrm{K}$ deficiency and rainfall reduction (37\% throughfall exclusion) on the water used by the trees, soil water storage and water table fluctuations over the first 4.5 years after planting Eucalyptus grandis trees. A comparison of canopy transpiration in each plot with the values predicted for the same soil with the water content maintained at field capacity, made it possible to calculate a soil-driven tree water stress index for each treatment. Compared to K-fertilized trees with undisturbed rainfall $(+\mathrm{K}+\mathrm{W})$, canopy transpiration was $40 \%$ lower for $\mathrm{K}$ deficiency $(-\mathrm{K}+\mathrm{W}), 20 \%$ lower for $\mathrm{W}$ deficit $(+\mathrm{K}-\mathrm{W})$ and $36 \%$ lower for combined $\mathrm{K}$ deficiency and $\mathrm{W}$ deficit $(-\mathrm{K}-\mathrm{W})$ on average. Water was withdrawn in deeper soil layers for $-\mathrm{W}$ than for $+\mathrm{W}$, particularly over dry seasons. Under contrasted $\mathrm{K}$ availability, water withdrawal was more superficial for $-\mathrm{K}$ than for $+\mathrm{K}$. Mean soil water content down to $18 \mathrm{~m}$ below surface (mbs) was $24 \%$ higher for $-\mathrm{K}+\mathrm{W}$ than for $+\mathrm{K}+\mathrm{W}$ from 2 years after planting (after canopy closure), while it was $24 \%$ lower for $+\mathrm{K}-\mathrm{W}$ and $12 \%$ lower for $-\mathrm{K}-\mathrm{W}$ than for $+\mathrm{K}+\mathrm{W}$. The soil-driven tree water stress index was $166 \%$ higher over the first 4.5 years after planting for $-\mathrm{W}$ than for $+\mathrm{W}$, 76\% lower for $-\mathrm{K}$ than for $+\mathrm{K}$, and $14 \%$ lower for $-\mathrm{K}-\mathrm{W}$ than for $+\mathrm{K}+\mathrm{W}$. Over the study period, deep seepage was higher by $371 \mathrm{~mm} \mathrm{yr}^{-1}(+122 \%)$ for $-\mathrm{K}$ than for $+\mathrm{K}$ and lower by $200 \mathrm{~mm} \mathrm{yr}^{-1}(-66 \%)$ for $-\mathrm{W}$ than for $+\mathrm{W}$. Deep seepage was lower by $44 \%$ for $-\mathrm{K}-\mathrm{W}$ than for $+\mathrm{K}+\mathrm{W}$. At the end of the study period, the model predicted a higher water table for $-\mathrm{K}(10 \mathrm{mbs}$ for $-\mathrm{K}+\mathrm{W}$ and $16 \mathrm{mbs}$ for $-\mathrm{K}-\mathrm{W})$ than for $+\mathrm{K}(16 \mathrm{mbs}$ for $+\mathrm{K}+\mathrm{W}$ and $18 \mathrm{mbs}$ for $+\mathrm{K}-\mathrm{W}$ ). Our study suggests that flexible fertilization regimes could contribute to adjusting the local trade-off between wood production and demand for soil water resources in planted forests.
\end{abstract}

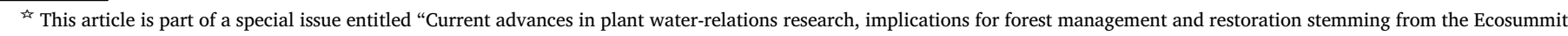
2016 conference", published in the Journal of Forest Ecology and Management 418, 2018.

* Corresponding author at: UPR AIDA, CIRAD, 2 Avenue Agropolis, 34398 Montpellier Cedex 5, France.

E-mail address: mathias.christina@cirad.fr (M. Christina). 


\section{Introduction}

Planted forests provided $46 \%$ of the wood consumption worldwide in 2012, and 65\% in tropical and subtropical regions (Payn et al., 2015). In tropical and subtropical regions, the growth of these highly productive planted forests is largely dependent on fertilization regimes (e.g. Smethurst, 2010) and their contribution to satisfying the global wood demand should increase in the future (Paquette and Messier, 2010). However, climate change is expected to exacerbate the intensity and frequency of droughts in tropical and subtropical regions (Allison et al., 2009; IPCC, 2013; Solomon et al., 2009). Fast-growing tropical plantations are particularly vulnerable to drought and changes in rainfall patterns (Allen, 2009). Consequently, the sustainability of fastgrowing planted forests in a future with extended dry periods in many tropical regions will probably require a revision of management strategies to improve tree tolerance to drought (Battie-Laclau et al., 2014a, 2016; Carter and White, 2009).

Water storage in deep soil layers is likely to have a major effect on tree functioning in tropical regions (Malhi et al., 2008). Indeed, water uptake by deep roots is generally considered as an efficient adaptation to drought in tropical forests to maintain transpiration rates during dry periods by withdrawing water from soil deeper than 8 to $10 \mathrm{~m}$ below surface (mbs) (Christina et al., 2017; Markewitz et al., 2010; Nepstad et al., 1994). Water uptake in the capillary fringe above the water table is likely to account for a substantial proportion of tree water use in eucalypt forests (Dawson and Pate, 1996; Zolfaghar et al., 2014; Eamus et al., 2015), even under relatively high rainfall regimes (approx. $1500 \mathrm{~mm} \mathrm{yr}^{-1}$ ) for water tables at $10 \mathrm{mbs}-18 \mathrm{mbs}$ (Christina et al., 2017). Recent studies have shown that tree water stress and mortality are dependent on the amount of water stored in deep soil layers in Australian eucalypt forests (Harper et al., 2009; Brouwers er al., 2013; Zolfaghar et al., 2014), in the Amazonian Forest (da Costa et al., 2010; Malhi et al., 2009) and in the Brazilian savanna (Jackson et al., 1999; Oliveira et al., 2005). In consequence, modifications to current management practices in drought-prone planted forests have been proposed to decrease tree water stress during dry periods. The most common silvicultural adaptations proposed are: (i) to plant species and hybrids selected by breeding programs for their high tolerance to drought (Dutkowski et al., 2012; Rojas et al., 2017), (ii) to decrease the stocking densities (Mendham et al., 2011; White et al. 2009) or rotation periods, to restore soil water storage after clear-cutting (Harper et al., 2014), (iii) to reduce the amounts of fertilizer applied (Forrester et al., 2013; Battie-Laclau et al., 2014a; White et al., 2009), and (iv) to concentrate future afforestation programs on deep soils (Harper et al., 2014; BattieLaclau et al., 2016).

Although it is well established that an adequate nutritional status helps plant tolerance to abiotic stresses (Cakmak, 2005; Reddy et al., 2004), carbon partitioning to wood production (Litton et al., 2007; Epron et al., 2012), and water-use efficiency (White et al., 2014; BattieLaclau et al., 2016), some studies have shown that fertilization is likely to increase tree water stress during dry periods (Linder et al., 1987; White et al., 2009), for example by increasing leaf area. Measurements (Battie-Laclau et al., 2014a, 2016) as well as modeling approaches (Christina et al., 2015) in a field experiment manipulating throughfall and potassium (K) supply showed that a decrease in $\mathrm{K}$ fertilizer relative to current practices in commercial eucalypt plantations might help reduce tree water stress during drought through lower water use and increased water storage in deep soil layers during rainy seasons.

Concerns have been raised since the new millennium about the impact of highly productive eucalypt plantations on groundwater resources and stream flow in tropical regions (Cossalter and Pye-Smith, 2003; Farley et al., 2005). In a future drier climate, management practices should be adapted to maintain wood production while limiting adverse consequences on groundwater resources. Our study aimed to gain insight into the effects of contrasting $\mathrm{K}$ nutrition and water supply regimes on tree water use and water seepage under highly productive Eucalyptus plantations in tropical soils. We hypothesized that: (i) a decrease in rainfall reduces tree water use and groundwater recharge, but increases tree water stress and the depth of water uptake in the soil and (ii) a decrease in $\mathrm{K}$ fertilization could mitigate the adverse consequences of low precipitation on tree water stress and soil water resources.

\section{Material and methods}

\subsection{Site description}

The experiment was conducted at the Itatinga Experimental Station of the University of São Paulo in Brazil (23 $3^{\circ} 020 S ; 48^{\circ} 380 \mathrm{~W}$ ). From 2010 to 2014, the mean annual precipitation was $1578 \mathrm{~mm} \mathrm{yr}^{-1}$, with a drier year in $2014\left(1189 \mathrm{~mm} \mathrm{yr}^{-1}\right)$ at this site. The dry season lasted from June to September with a mean monthly temperature of $15{ }^{\circ} \mathrm{C}$, and the rainy season was from October to May, with a mean monthly temperature of $25^{\circ} \mathrm{C}$ and higher overall PAR. The experiment was located on a hilltop (slope $<3 \%$ ) at an altitude of 850 MASL. The soils were very deep Ferralsols ( $>15 \mathrm{~m}$; Christina et al., 2011) developed on Cretaceous sandstone, with clay content ranging from 14\% in the top soil to $23 \%$ in deep soil layers (Laclau et al., 2010).

The experiment was described in detail by -Laclau et al. (2014a). A split-plot experimental design was set up in June 2010 with a highly productive Eucalyptus grandis clone used in commercial plantations by the Suzano Company (São Paulo, Brazil). Two K fertilization regimes $(+/-\mathrm{K})$ and two water supply regimes $(+/-\mathrm{W})$ were applied in three blocks. The area of the individual plots was $864 \mathrm{~m}^{2}$ (144 trees per plot). The four treatments were:

- $+\mathrm{K}+\mathrm{W}$ : $\mathrm{K}$ fertilization $\left(0.45 \mathrm{~mol} \mathrm{~K} \mathrm{~m}^{-2}\right.$ applied as $\left.\mathrm{KCl}\right)$ and no throughfall exclusion,

- $-\mathrm{K}+\mathrm{W}$ : no $\mathrm{K}$ fertilization and no throughfall exclusion,

- $+\mathrm{K}-\mathrm{W}$ : $\mathrm{K}$ fertilization and about $37 \%$ throughfall exclusion,

- $-\mathrm{K}-\mathrm{W}$ : no $\mathrm{K}$ fertilization and about $37 \%$ throughfall exclusion.

$\mathrm{K}$ fertilizer was applied 3 months after planting and the amount was calculated to be a non-limiting factor at our study site (Almeida et al., 2010). Before fertilization, mean exchangeable $\mathrm{K}$ was ranging from $0.02 \mathrm{cmolc} \mathrm{kg}^{-1}$ in the upper soil layer and $<0.01 \mathrm{cmolc} \mathrm{kg}^{-1}$ between $0.05 \mathrm{mbs}$ and $15 \mathrm{mbs}$ (Laclau et al., 2010). Other amendments $\left(3.3 \mathrm{~g} \mathrm{P} \mathrm{m}^{-2}, 200 \mathrm{~g} \mathrm{~m}^{-2}\right.$ of dolomitic lime and trace elements) were applied at planting for all treatments and at 3 months after planting $\left(12 \mathrm{~g} \mathrm{~N} \mathrm{~m}^{-2}\right)$; this was not limiting for tree growth at this study site (Laclau et al., 2009). Manual weeding was done in the first months after planting and then glyphosate was applied before canopy closure to totally eliminate weeds in the experiment. Leaf cutting ants were controlled before planting using sulfluramide based baits. A manual hole was made for planting. Throughfall was excluded using panels made of clear, PAR-transmitting greenhouse plastic sheets mounted on wooden frames at a height of $1.6 \mathrm{~m}-0.5 \mathrm{~m}$. Plastic sheets ( $37 \mathrm{~cm}$ in width) were set up in the throughfall exclusion plots to cover $37 \%$ of the area, and the throughfall exclusion amounted to $\sim 450 \mathrm{~mm} \mathrm{y}^{-1}$. Photographs of the design can be found in Battie-Laclau et al. (2014a,b).

Meteorological data were obtained from June 2010 to December 2014 using an automatic weather station placed at the top of a $21 \mathrm{~m}$ high tower located at $50 \mathrm{~m}$ from the experiment at a half-hourly time step. The following data were used as inputs to the MAESPA model: incident total short-wave radiation ( $\mathrm{RAD}, \mathrm{W} \mathrm{m}^{-2}$ ), air temperature (Tair, $\left.{ }^{\circ} \mathrm{C}\right)$, relative humidity $(\mathrm{RH}, \%)$, atmospheric pressure (Press, $\mathrm{Pa}$ ), wind speed above the canopy (Wind, $\mathrm{m} \mathrm{s}^{-1}$ ) and precipitation (PPT, $\mathrm{mm}$ ). Annual precipitations were 1834, 1622, 1714 and $1103 \mathrm{~mm} \mathrm{yr}^{-1}$ in 2011, 2012, 2013 and 2014 (an exceptionally dry year), respectively.

Measured canopy transpiration was estimated using sap flow measurements at tree scale (see Battie-Laclau et al. 2016 for details) to be compared with model simulation. The sap flow density was measured 
from July 2011 to June 2013 in 10 to 13 trees, throughout the range of cross-sectional area in each treatment, at a 30-min time step, using a calibration equation determined in a preliminary study (Delgado-Rojas et al., 2010, slope $=0.97$ and $\mathrm{R}^{2}=0.94$ between predicted and measured values of tree transpiration). In each treatment, a linear regression was performed between the daily sap flow of each tree and the circumference at breast height $(\mathrm{CBH})$. These regressions were then used to estimate the daily stand-scale canopy transpiration from the $\mathrm{CBH}$ of all the trees in each inner plot. Soil water content was measured with 3 TDR probes per treatment (Trase Soilmoisture, Santa Barbara, CA, USA) at $0.5,1.5,3.0,4.5$ and 6.0 mbs over the study period, to be compared with model simulation.

\subsection{MAESPA model}

The MAESPA model (Duursma and Medlyn, 2012) is a model coupling the above-ground components of the MAESTRA model (Medlyn et al., 2007; Wang and Jarvis, 1990) and the water balance components of the SPA model (Williams et al., 2001a, 2001b), with several changes and additions (Christina et al., 2017) in particular in the soil water balance model (water table dynamics, capillary rising,...) and stomatal conductance model. The model has a long history of development and applications on diverse forest types (see the bibliography at http:// maespa.github.io/bibliography.html). A 3D single-tree based model calculates light interception and distribution within the tree crowns to estimate the absorbed photosynthetically active radiation for individual trees in the stand, considering neighboring trees that compete for light. A leaf physiology model is used to estimate photosynthesis and transpiration at the leaf scale (Medlyn, 1998). The water balance is based on a soil-root-leaf-air water potential gradient and on the hydraulic conductivity between these compartments. The tree canopy is divided in small grid cells and transpiration is calculated from the PenmanMonteith equation applied to the small volumes of leaves inside. There were two methods for calculating transpiration: one using the Penman-Monteith equation applied to small volumes of leaves and the other simulating the water flow from the soil to the leaves based on water potential gradients and hydraulic conductivity. The leaf water potential, which was used to calculate the leaf stomatal conductance (Tuzet et al., 2003), was estimated iteratively to ensure that the two transpiration rate calculations matched. In the Tuzet et al. (2003) model, stomatal conductance depends on leaf water potential, which summarize the effect of both vapour pressure deficit and soil water potential. The soil is considered as horizontally uniform. Water uptake is distributed between the soil layers depending on the fine root density and soil water potential. The soil water storage in each layer is calculated as the balance between infiltration, soil evaporation, drainage, root water uptake, capillary rising and lateral groundwater flow. The fraction of roots in each layer is an input parameter in the model as well as root characteristics such as root diameter, specific root length and total root biomass. Root systems are assumed to be horizontally homogeneous under the whole stand. The equations and mechanisms driving the water balance were described in Duursma and Medlyn (2012) with some modifications detailed in Christina et al. (2017; supplementary information).

\subsection{MAESPA parameterization}

The MAESPA model has been parameterized over the first 3 years after planting for the studied site using a split-plot design with combinations of $\mathrm{K}$ nutrition and water supply regimes (Christina et al., 2015, Appendix Table A2). In addition, the leaf area index, crown morphology, tree height and leaf angle measurements were extended to 4.5 years after planting in all the treatments using the methods described in Christina et al. (2015). The positions of each tree within the plot were specified in MAESPA. The tree height, crown length and radius, and leaf area of each tree were calculated based on inventories and destructive measurements of eight trees carried out in each plot monthly from 6 to 17 months after planting and then at ages 23, 27, 31, 36 and 48 months. The tree size parameters were estimated by linear interpolation between each inventory. Age-specific allometric relationships between leaf area and the tree size were determined for each treatment and then applied to estimate leaf area for all the trees in the plots for each treatment using inventory data. Belowground model parameters are given in appendix (Table A3). We assumed that soil hydraulic conductivity decreased linearly between $3 \mathrm{mbs}$ and $8 \mathrm{mbs}$, and remained constant below $8 \mathrm{mbs}$. In each treatment, the minimum soil water content for root absorption was the lowest volumetric water content measured by TDR probes at each depth over the study period (Christina et al., 2015) and we assumed a linear increase with soil depth down to $18 \mathrm{mbs}$ (as in Christina et al., 2017). The soil profile is divided in $50 \mathrm{~cm}$ thick soil layers down to $18 \mathrm{mbs}$, with soil characteristics and root densities specified for each layer.

The experiment was established close to a hilltop and monthly measurements of the water table (using three piezometers) showed that it fluctuated throughout the first 4.5 years after planting between $15 \mathrm{mbs}$ and $17 \mathrm{mbs}$, with small differences between treatments. Large amounts of deep drainage in a neighboring stand with a very low leaf area index (LAI) at the top of the hill influenced the water table within the experimental site, with a rise of $1-2 \mathrm{~m}$ at the end of each rainy season, independently of the treatment. The small area of each treatment within the field trial did not make it possible to measure the effects of the $\mathrm{K}$ and $\mathrm{W}$ supply regimes on the water table depth in each treatment. For this, very large stand would have been necessary, which was not technically possible. A modeling approach was therefore used to explore the impact of these treatments on the water table present in each plot at the same depth at planting, and to assess the consequences of different $\mathrm{K}$ nutrition and water supply regimes on soil water resources in commercial Eucalyptus plantations covering large areas. The initial water table depth and the lateral groundwater flow used for the simulations were measured in a nearby 90 ha commercial Eucalyptus plantation growing on the same soil type and studied in detail in Christina et al. (2017). All the other parameters used in the MAESPA model (soil and plant parameters) were specifically determined from measurements in the experiment manipulating $\mathrm{K}$ and $\mathrm{W}$ supply regimes, as described above (Appendix Tables A1, A2 \& A4). Measurements in the 90 ha commercial stand showed the water table initially at $18.5 \mathrm{mbs}$ at planting and had a lateral groundwater flow of $\sim 0.5 \mathrm{~mm} \mathrm{~d}^{-1}$ (Christina et al., 2017). Finally, simulations were performed for each of the 36 inner trees in each plot over the 4.5 years after planting at a $15 \mathrm{~min}$ time step. Six lines of trees were added as buffer rows in the simulations to take into account the radiation environment of the 36 target trees.

\subsection{MAESPA predictions and comparison with measurements}

Daily transpiration was estimated for each tree and summed over all the inner plots of each treatment. It was then divided by the area of the inner plots to estimate the stand-scale canopy transpiration $\left(\mathrm{T}_{\mathrm{C}}, \mathrm{mm}\right.$ $\left.\mathrm{d}^{-1}\right)$. Each day, the depths of soil layers were weighted by the fraction of water withdrawn from each layer to estimate the weighted uptake depth ( $\left.D_{\text {UPT }}, \mathrm{mbs}\right)$. For a particular day, the weighted uptake depth was calculated as follows:

$D_{U P T}=\frac{\sum_{i} D_{i} * U P T_{i}}{\sum_{i} U P T_{i}}$,

where $\mathrm{UPT}_{\mathrm{i}}$ is the water withdrawn from layer $\mathrm{i}\left(\mathrm{mm} \mathrm{d}^{-1}\right)$, and $\mathrm{D}_{\mathrm{i}}$ is the depth of layer i (mbs) from the soil surface to the depth of the water. Water uptake from the capillary fringe of the water table was included.

A soil-driven water stress index was calculated to assess the consequences of soil water limitation on tree water status. We predicted the stand-scale canopy transpiration over the 4.5 years of growth with the 
soil water content forced to field capacity throughout the soil profile $\left(\mathrm{T}_{\mathrm{C} \text {,sat_soil }}\right)$, while all other parameters were identical to the simulation with non-forced soil water content. $\mathrm{T}_{\mathrm{C} \text {,sat_soil }}$ was influenced by canopy structural characteristics (e.g. leaf area index, leaf angles, tree position and sizes), by meteorological conditions (e.g. global radiation, vapor pressure deficit) but not by soil water content. As a consequence, $\mathrm{T}_{\mathrm{C}}$ is always lower (when there is. soil-driven water stress) or equal to

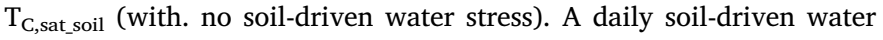
stress index $\left(\mathrm{I}_{\mathrm{Sws}, \mathrm{d}}\right)$ was, therefore, calculated from the ratio between daily $\mathrm{T}_{\mathrm{C}}$ and daily $\mathrm{T}_{\mathrm{C} \text {,sat_soil: }}$

$I_{S W S, d}=1-\frac{T_{C}}{T_{C, \text { sat soil }}}$,

Similarly, a total soil-driven water stress index over the whole growth period was calculated as follows:

$I_{S W S, t o t}=1-\frac{\sum_{i} T_{C, i}}{\sum_{i} T_{C, \text { sat soil }, i}}$,

where, $\mathrm{T}_{\mathrm{C}, \mathrm{i}}$ and $\mathrm{T}_{\mathrm{C} \text {,sat_soil,i }}$ are the $\mathrm{T}_{\mathrm{C}}$ and $\mathrm{T}_{\mathrm{C} \text {,sat_soil }}$ at day $\mathrm{i}$ (from planting date to 4.5 years), respectively.

Total deep seepage was calculated as the sum of the lateral groundwater flow over the first 4.5 years after planting and the difference in the groundwater stocks after 4.5 years (difference between final and initial groundwater stocks above $18 \mathrm{mbs}$ ). The deep seepage corresponds to the part of the water that will mostly be available for stream flow in the long term (blue water). Canopy transpiration, soil water content, weighted water uptake depth, deep seepage and water storage throughout the soil profiles were predicted for each plot of the split-plot experiment and averaged per treatment.

The model outputs for canopy transpiration $\left(\mathrm{T}_{\mathrm{C}}\right)$ and soil water content $(\theta)$ were compared to measurements made at the same site. Predicted daily $\mathrm{T}_{\mathrm{C}}$ for each treatment was compared to sap flow measurements carried out by Battie-Laclau et al. (2016) from 1 to 3 years after planting.

\section{Results}

3.1. Comparison between predicted and measured stand transpiration and soil water content

In general the predicted canopy transpiration $\left(\mathrm{T}_{\mathrm{C}}\right)$ was a good fit to the measurements (Fig. 1). Root mean square errors (RMSE) between daily measurements and predictions ranged from 0.63 to $1.08 \mathrm{~mm} \mathrm{~d}^{-1}$ (from 4 to 16\%), depending on the treatment. Over the two years of measurements, canopy transpiration was underestimated by $6 \%$ for $+\mathrm{K}$ $+\mathrm{W}$ and $16 \%$ for $+\mathrm{K}-\mathrm{W}$ and was over-estimated by $9 \%$ for $-\mathrm{K}+\mathrm{W}$ and $15 \%$ for $-\mathrm{K}-\mathrm{W}$.

There was good overall agreement between predicted and measured soil water content $(\theta)$ over the study period, for all treatments and soil depths (Fig. 2). The RMSEs between predicted and measured $\theta$ over the first 4.5 years after planting, across all the soil depths equipped with TDR probes, were similar in all treatments (RMSE $=0.020-0.023 \mathrm{~m}^{3} \mathrm{~m}^{-3}$ ). The small discrepancies between measured and predicted $\mathrm{T}_{\mathrm{C}}$ and $\theta$ (down to $6 \mathrm{mbs}$ ) in all the treatments suggest that our simulations of water fluxes throughout the soil profiles were realistic.

\subsection{Canopy transpiration and tree water stress}

The effects of $\mathrm{K}$ and $\mathrm{W}$ supply regimes on canopy transpiration $\left(\mathrm{T}_{\mathrm{C}}\right)$ changed over the tree growth period (Fig. 3). For $+\mathrm{K}+\mathrm{W}, \mathrm{T}_{\mathrm{C}}$ sharply increased after planting up to approximately $3 \mathrm{~mm} \mathrm{~d}^{-1}$ at one year of age, then reached maximum values of $5-6 \mathrm{~mm} \mathrm{~d}^{-1}$ in the successive rainy seasons. For $+\mathrm{K}+\mathrm{W}, \mathrm{T}_{\mathrm{C}}$ in the dry season was about half that in the rainy season. The predicted $\mathrm{T}_{\mathrm{C}}$ for $+\mathrm{K}-\mathrm{W}$ was similar to that for $+\mathrm{K}+\mathrm{W}$ the first year after planting, after which $\mathrm{T}_{\mathrm{C}}$ was limited to maximum values of about $4 \mathrm{~mm} \mathrm{~d}^{-1}$ for $+\mathrm{K}-\mathrm{W}$ in the rainy seasons. For $-\mathrm{K}+\mathrm{W}$ and $-\mathrm{K}-\mathrm{W}, \mathrm{T}_{\mathrm{C}}$ increased up to $2 \mathrm{~mm} \mathrm{~d}^{-1}$ the first year

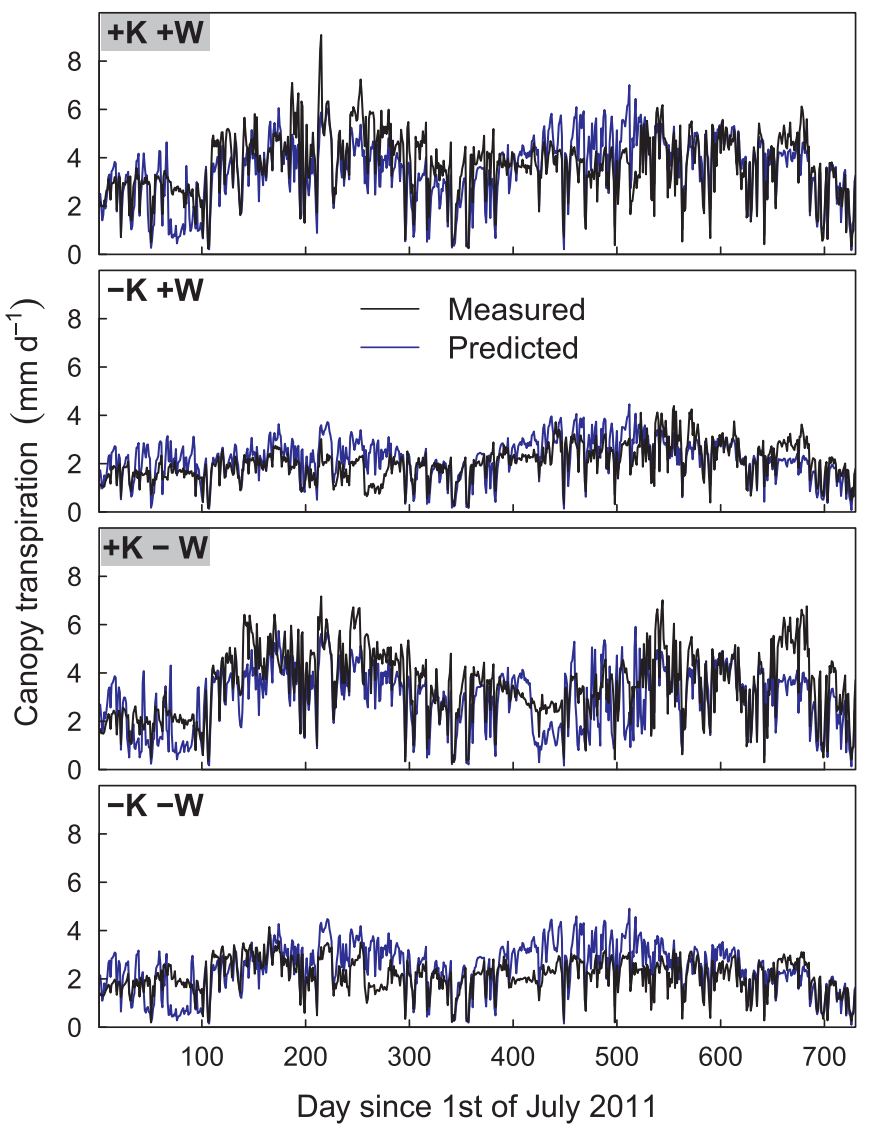

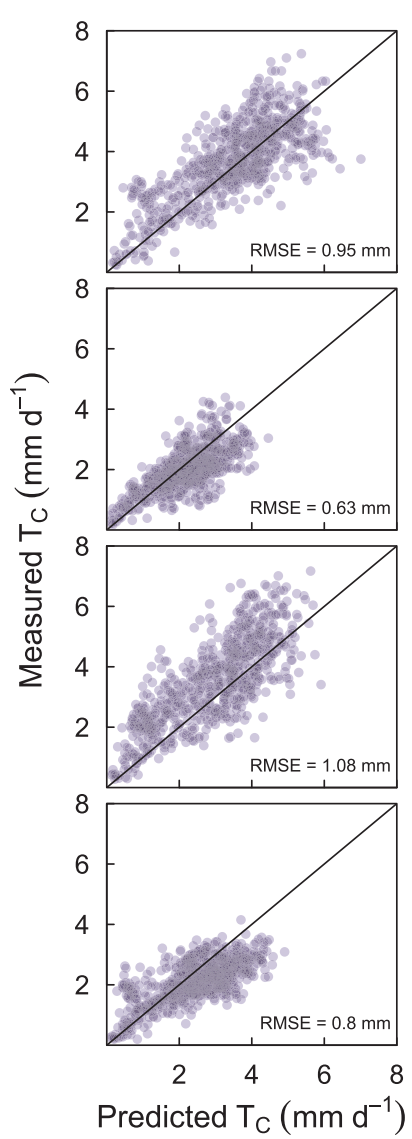

Fig. 1. Comparison between daily predicted (blue line) and measured (black line) canopy transpiration from 1 to 2 years after planting in Eucalyptus grandis plantations for different $\mathrm{K}$ nutrition and water supply regimes. $-\mathrm{K}$ and $+\mathrm{K}$ are for the $\mathrm{K}$ deficient and $\mathrm{K}$-fertilized trees, respectively. $+\mathrm{W}$ and $-\mathrm{W}$ are for undisturbed rainfall and exclusion of $37 \%$ of throughfall, respectively. (For interpretation of the references to colour in this figure legend, the reader is referred to the web version of this article.) 


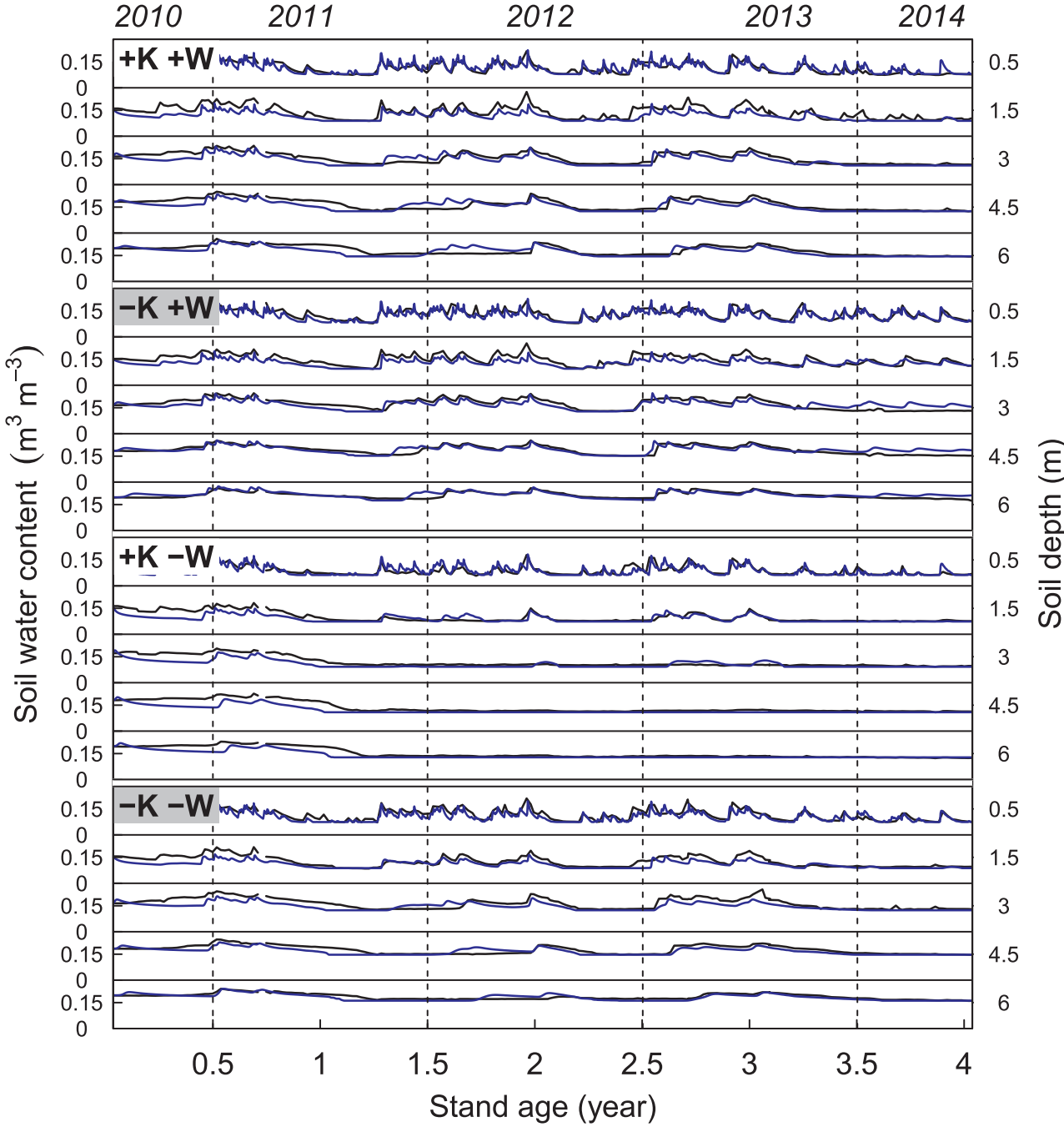

Fig. 2. Predicted (blue line) and measured (black line) daily volumetric soil water content $(\theta)$ over the first 4 years after planting Eucalyptus grandis trees for different $\mathrm{K}$ nutrition and water supply regimes. $\theta$ was measured in each treatment at $0.5 \mathrm{mbs}, 1.5 \mathrm{mbs}, 3 \mathrm{mbs}, 4.5 \mathrm{mbs}$ and $6 \mathrm{mbs}$, using TDR probes. $-\mathrm{K}$ and $+\mathrm{K}$ are for the $\mathrm{K}$-deficient and K-supplied trees, respectively. $+\mathrm{W}$ and $-\mathrm{W}$ are for undisturbed rainfall and exclusion of $37 \%$ of throughfall, respectively. (For interpretation of the references to colour in this figure legend, the reader is referred to the web version of this article.) after planting and remained below $3 \mathrm{~mm} \mathrm{~d}^{-1}$ for the rest of the study period. The effects of $\mathrm{K}$ deficiency and $\mathrm{W}$ deficit on $\mathrm{T}_{\mathrm{C}}$ were therefore more pronounced after canopy closure (at about 1.5 years of age) than earlier. $\mathrm{T}_{\mathrm{C}}$ for $+\mathrm{K}-\mathrm{W}$ was $270-517 \mathrm{~mm} \mathrm{y}^{-1}$ less than for $+\mathrm{K}+\mathrm{W}$ after canopy closure (Table 1), which represented an overall decrease of $20 \%$ over the study period (Fig. $5 \mathrm{a}$ ). $\mathrm{T}_{\mathrm{C}}$ for both $-\mathrm{K}+\mathrm{W}$ and $-\mathrm{K}-\mathrm{W}$ was 231-685 $\mathrm{mm} \mathrm{y}^{-1}$ less than for $+\mathrm{K}+\mathrm{W}$ (Table 1 ), which represented an overall decrease of $38 \%$ (Fig. $5 \mathrm{a}$ ). The dynamics of tree transpiration over time and change between $\mathrm{K}$ and $\mathrm{W}$ availability followed the change in leaf area index observed in our experiment and presented in previous studies (Battie-Laclau et al., 2014a, 2016; Christina et al., 2015). In average, LAI decreased by $45 \%$ for both $-\mathrm{K}+\mathrm{W}$ and $-\mathrm{K}-\mathrm{W}$, compared to $+\mathrm{K}+\mathrm{W}$. In comparison, LAI was $10 \%$ lower in $+\mathrm{K}-\mathrm{W}$ compared to $+\mathrm{K}+\mathrm{W}$, over the growth period, but this difference increased over the growth. The consequences in term of total aboveground net primary production was similar and presented in BattieLaclau et al. (2016).

For $+\mathrm{K}+\mathrm{W}$ the model predicted only short periods with daily soildriven tree water stress $\left(\mathrm{I}_{\mathrm{Sws}, \mathrm{d}}\right)>0.2$ at the end of the dry seasons (Fig. 3). However, for $-\mathrm{K}+\mathrm{W}$; $\mathrm{I}_{\mathrm{SwS}, \mathrm{d}}$ was low throughout the tree growth period, except during one short climatic event about 1 year after planting. For $+\mathrm{K}-\mathrm{W}, \mathrm{I}_{\mathrm{Sws}, \mathrm{d}}$ was high in each dry season and remained greater than 0.4 most days from 3.5 years onwards. For $-\mathrm{K}-\mathrm{W}$, $\mathrm{I}_{\mathrm{Sws}, \mathrm{d}}$ was slightly lower than for $+\mathrm{K}+\mathrm{W}$ over the study period, even the fourth year after planting which was particularly dry. $I_{S w s, d}$ was only greater than 0.1 only when the available soil water content in the layers with roots was less than $0.02 \mathrm{~m}^{3} \mathrm{~m}^{-3}$, except for $+\mathrm{K}-\mathrm{W}$, where the threshold value was $0.04 \mathrm{~m}^{3} \mathrm{~m}^{-3}$.

The soil-driven tree water stress index over the growth period ( $\mathrm{I}_{\text {SWs,tot }}$ ) was strongly influenced by $\mathrm{K}$ and $\mathrm{W}$ supply regimes (Fig. 5b). $\mathrm{I}_{\mathrm{SWS}, \text { tot }}$ for $+\mathrm{K}-\mathrm{W}$ was $+166 \%$ higher than for $+\mathrm{K}+\mathrm{W}$ and for $-\mathrm{K}$ $+\mathrm{W}$ it was $76 \%$ lower than for $+\mathrm{K}+\mathrm{W}$. $\mathrm{I}_{\mathrm{Sws} \text {, tot }}$ for $-\mathrm{K}-\mathrm{W}$ was slightly lower $(-14 \%)$ than for $+\mathrm{K}+\mathrm{W}$. and $38 \%$ lower than for $+\mathrm{K}-\mathrm{W}$.

\subsection{Water uptake depth}

While contrasting $\mathrm{K}$ and $\mathrm{W}$ supply regimes strongly affected annual $\mathrm{T}_{\mathrm{C}}$, water uptake depth was little affected by the treatments up to age 2 years (Fig. 4). However, water uptake depth sharply increased in Kfertilized stands the fourth year after planting, which had exceptionally low rainfall at our study site (Table 1 ), with mean annual values of approx. $6 \mathrm{mbs}$ for $+\mathrm{K}-\mathrm{W}, 4 \mathrm{~m}$ for $+\mathrm{K}+\mathrm{W}$ and about only $2 \mathrm{mbs}$ for $-\mathrm{K}+\mathrm{W}$ and $-\mathrm{K}-\mathrm{W}$. For $-\mathrm{K}+\mathrm{W}$ the fluctuations in water uptake depth were much smaller throughout the fourth year after planting than for the other treatments. The water uptake depth was much greater in dry seasons than rainy seasons, with little differences between treatments up to 3 years (Fig. 4). In the dry season of the fourth year after planting, the mean water uptake depth was only about $2 \mathrm{mbs}$ for $-\mathrm{K}$ $+\mathrm{W}$ (with a low temporal variability) whereas it reached 7-9 mbs for the other treatments (with a high temporal variability). Water withdrawal close to the water table hardly ever occurred for $-\mathrm{K}+\mathrm{W}$ and even $-\mathrm{K}-\mathrm{W}$ (Fig. 4, Table 1), while this occurred frequently from 2.5 years onwards for $+\mathrm{K}-\mathrm{W}$ and from 3.5 years onwards for $+\mathrm{K}+\mathrm{W}$, after the upper soil layers dried out. However, the simulation of the 


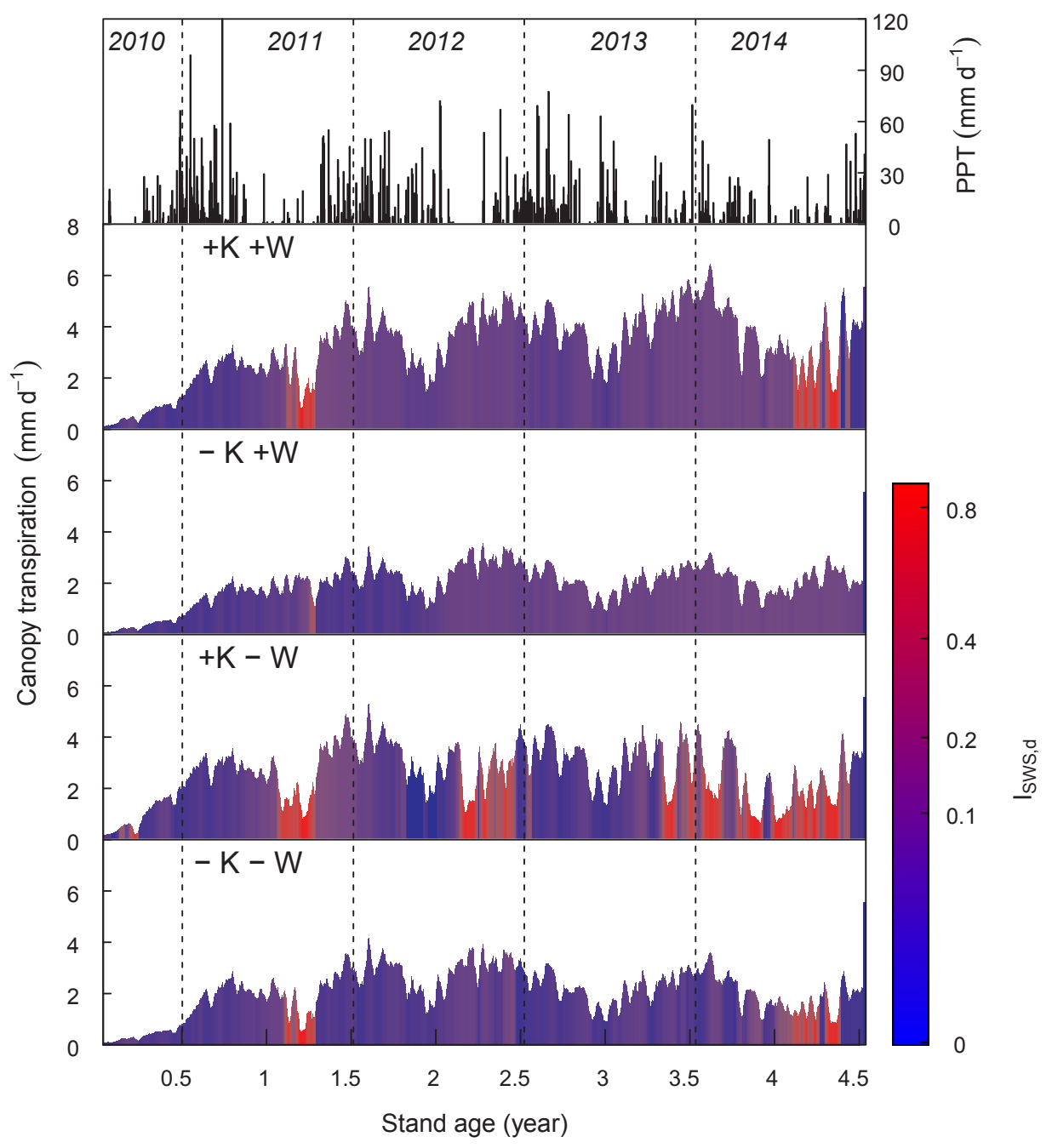

Fig. 3. Canopy transpiration $\left(\mathrm{T}_{\mathrm{C}}\right)$ in Eucalyptus grandis plots over 4.5 years after planting. $-\mathrm{K}$ and $+\mathrm{K}$ are for the K-deficient and K-supplied trees, respectively. + W and $-\mathrm{W}$ are for undisturbed rainfall and exclusion of $37 \%$ of throughfall, respectively. The daily soil-driven water stress index, $\mathrm{I}_{\mathrm{SWS}, \mathrm{d}}$ is shown as a color gradient (red for transpiration limited by soil water content, and blue for non limited transpiration). Daily precipitation (PPT) over the study period is shown in the upper graph. (For interpretation of the references to colour in this figure legend, the reader is referred to the web version of this article.)

water table depth was for a large stand with dynamics similar to another site previously studied $15 \mathrm{~km}$ away in the same catchment area. The implications of this modeling choice will be further discussed.

The model indicated that, during the first 2.5 years of growth, $88 \%$ of the water used by the trees was taken up in the upper $5 \mathrm{~m}$ for all treatments (Table 1). During the third year of growth, water uptake in the upper $5 \mathrm{~m}$ remained high in all treatments (84-91\%) except for $+\mathrm{K}$ $+\mathrm{W}$ where $76 \%$ of water was taken up in the upper $5 \mathrm{~m}$. For $+\mathrm{K}-\mathrm{W}$, $16 \%$ of the water was taken up below $5 \mathrm{mbs}$ and $11 \%$ in the capillary fringe. The water uptake in the water table capillary fringe reached $23 \%$ of tree water use the last year of growth (an exceptionally dry year) in both $-\mathrm{W}$ treatments $(+\mathrm{K}-\mathrm{W}$ and $-\mathrm{K}-\mathrm{W})$. On the contrary, even during an exceptionally dry year, water uptake from the capillary fringe was almost non-existent for $-\mathrm{K}$ treatments.

\subsection{Soil water content and groundwater stocks}

The $\mathrm{K}$ and $\mathrm{W}$ supply regimes strongly influenced soil water content $(\theta)$ throughout the soil layers explored by fine roots (Fig. 4). $\theta$ was higher for $-\mathrm{K}+\mathrm{W}$ than for $+\mathrm{K}+\mathrm{W}$ and the differences increased with stand age. As expected, $\theta$ was lower for $+\mathrm{K}-\mathrm{W}$ and $-\mathrm{K}-\mathrm{W}$ than for $+\mathrm{K}+\mathrm{W}$.

The depth of the water table over the first 4.5 years after planting was highly dependent on the $\mathrm{K}$ nutrition and water supply regimes (Figs. 4 and $5 \mathrm{c}$ ). While the groundwater stocks (down to $18 \mathrm{mbs}$ ) decreased by $35 \mathrm{~mm} \mathrm{yr}^{-1}$ on average over the study period for $+\mathrm{K}+\mathrm{W}$, it decreased by $138 \mathrm{~mm} \mathrm{yr}^{-1}$ for $+\mathrm{K}-\mathrm{W}$ and increased by $288 \mathrm{~mm} \mathrm{yr}^{-1}$ for $-\mathrm{K}+\mathrm{W}$. The groundwater stocks decreased by only $23 \mathrm{~mm} \mathrm{yr}^{-1}$ for $-\mathrm{K}-\mathrm{W}$.

Water table depths were highly dependent on the K and W supply regimes (Fig. 4). The water table rose from $18 \mathrm{mbs}$ to $12 \mathrm{mbs}$ the first year after planting without throughfall exclusion $(+\mathrm{K}+\mathrm{W}$ and $-\mathrm{K}$ $+\mathrm{W}$ ). While the water table progressively fell to $16 \mathrm{mbs}$ at 4.5 years after planting for $+\mathrm{K}+\mathrm{W}$, it rose to $10 \mathrm{mbs}$ for $-\mathrm{K}+\mathrm{W}$. With throughfall exclusion $(+\mathrm{K}-\mathrm{W}$ and $-\mathrm{K}-\mathrm{W})$, the water table rose to about $14 \mathrm{mbs}$ after 1 year. The water table then fell slowly to $16 \mathrm{mbs}$ for $-\mathrm{K}-\mathrm{W}$ after 4.5 years because of lateral groundwater flows, while it fell to $18 \mathrm{mbs}$ for $+\mathrm{K}-\mathrm{W}$, as a result of water uptake from the capillary fringe. For K-fertilized trees, there was groundwater recharge by gravitational water in years with high rainfall but not in years with low rainfall (after the first year for $+\mathrm{K}-\mathrm{W}$ and in the fourth year after planting for $+\mathrm{K}+\mathrm{W}$ ). The groundwater recharge was much higher under K-deficient trees than under K-fertilized trees.

The deep seepage (Fig. 5d) was calculated as the sum of the lateral groundwater flow over the study period (Table 1 ) and the difference in the groundwater stocks (down to $18 \mathrm{mbs}$ ) between the end and the beginning of the study period. Deep seepage is a proxy of the soil water resources supplying the long-term stream flow in afforested catchment areas. Compared to standard silvicultural practices $(+K+W)$, deep seepage was $371 \mathrm{~mm} \mathrm{yr}^{-1}$ higher $(+122 \%)$ with $\mathrm{K}$ deficiency $(-\mathrm{K}$ $+\mathrm{W})$ and $200 \mathrm{~mm} \mathrm{yr}^{-1}$ lower (-66\%) with throughfall exclusion $(+\mathrm{K}-\mathrm{W})$. 
Table 1

Water fluxes over the study period for different $\mathrm{K}$ nutrition and rainfall supply regimes in Eucalyptus grandis plantations. The table shows annual canopy transpiration and water uptake by trees at different depths $(0-5 \mathrm{~m}, 5 \mathrm{~m}$ down to the water table, and at the capillary fringe of the water table), soil water storage in the vadose zone and lateral groundwater flows. Annual precipitation was $1834,1622,1714$ and $1103 \mathrm{~mm} \mathrm{yr}^{-1}$ from 0.5 to $1.5,1.5$ to $2.5,2.5$ to 3.5 and 3.5 to 4.5 years after planting, respectively.

\begin{tabular}{|c|c|c|c|c|}
\hline Stand age (year) & $+\mathrm{K}+\mathrm{W}$ & $-\mathrm{K}+\mathrm{W}$ & $+\mathrm{K}-\mathrm{W}$ & $-\mathrm{K}-\mathrm{W}$ \\
\hline & \multicolumn{4}{|c|}{ Canopy transpiration $\left(\mathrm{mm} \mathrm{yr}^{-1}\right)$} \\
\hline $0.5-1.5$ & 947 & 654 & 984 & 716 \\
\hline $1.5-2.5$ & 1365 & 881 & 1095 & 1035 \\
\hline $2.5-3.5$ & 1438 & 753 & 1110 & 792 \\
\hline \multirow[t]{2}{*}{$3.5-4.5$} & 1323 & 774 & 806 & 705 \\
\hline & \multicolumn{4}{|c|}{ Uptake $0-5 \mathrm{mbs}\left(\mathrm{mm} \mathrm{yr}^{-1}\right)$} \\
\hline $0.5-1.5$ & 840 & 598 & 859 & 639 \\
\hline $1.5-2.5$ & 1115 & 798 & 955 & 872 \\
\hline $2.5-3.5$ & 1088 & 644 & 933 & 722 \\
\hline $3.5-4.5$ & 796 & 647 & 543 & 523 \\
\hline \multicolumn{5}{|c|}{ Uptake $5 \mathrm{mbs}$ - water table $\left(\mathrm{mm} \mathrm{yr}^{-1}\right)$} \\
\hline $0.5-1.5$ & 107 & 56 & 125 & 77 \\
\hline $1.5-2.5$ & 233 & 78 & 140 & 163 \\
\hline $2.5-3.5$ & 341 & 84 & 50 & 70 \\
\hline $3.5-4.5$ & 221 & 118 & 79 & 182 \\
\hline \multicolumn{5}{|c|}{ Uptake from the capillary fringe ( $\left.m m \mathrm{yr}^{-1}\right)$} \\
\hline $0.5-1.5$ & 0 & 0 & 0 & 0 \\
\hline $1.5-2.5$ & 17 & 5 & 0 & 0 \\
\hline $2.5-3.5$ & 9 & 25 & 127 & 0 \\
\hline $3.5-4.5$ & 306 & 9 & 184 & 0 \\
\hline \multicolumn{5}{|c|}{ Vadose soil water storage $\left(\mathrm{mm} \mathrm{yr}^{-1}\right)$} \\
\hline $0.5-1.5$ & +387 & +614 & -111 & +106 \\
\hline $1.5-2.5$ & -143 & +241 & -241 & -248 \\
\hline $2.5-3.5$ & -256 & +220 & -285 & +2 \\
\hline $3.5-4.5$ & -524 & -208 & -92 & -157 \\
\hline \multicolumn{5}{|c|}{ Groundwater lateral flow (mm $\left.\mathrm{yr}^{-1}\right)$} \\
\hline $0.5-1.5$ & 291 & 287 & 144 & 132 \\
\hline $1.5-2.5$ & 350 & 443 & 170 & 172 \\
\hline $2.5-3.5$ & 308 & 532 & 112 & 126 \\
\hline $3.5-4.5$ & 174 & 470 & 23 & 96 \\
\hline
\end{tabular}

\section{Discussion}

\subsection{Simulation reliability}

The discrepancies between measured and predicted values were relatively small in our study for stand transpiration and soil water contents, which suggests that the effects of K nutrition and water supply regimes on soil water resources were predicted reliably. Nevertheless, canopy transpiration estimates might be affected by several sources of uncertainty such as the rough estimation of the variation of Leaf Area Index (LAI) and root depth with time, which may affect predicted transpiration, and uncertainties associated with sap flow measurements (Köstner et al., 1998). While linear interpolation between the destructive LAI measurements made at about 6 month intervals limited the intra-annual variations in LAI, destructive (Christina et al. 2017) and remote sensing measurements (le Maire et al., 2011) made at higher frequencies in nearby Eucalyptus plantations showed that seasonal LAI changes can be more rapid. Also, despite using sap flow probes specifically calibrated for $E$. grandis trees at our study site, there may still be uncertainties associated with sap flow measurements and their extrapolation to the whole stand. The soil water content down to $6 \mathrm{mbs}$ was satisfactorily predicted over the study period in the 4 treatments, as in a previous study using the MAESPA model in E. grandis plantations (Christina et al., 2017).

The depth of the water table is site-dependent and cannot change over short distances in a field experiment with throughfall exclusion. Our objective here was not to predict the water table variations for the experiment, but to predict the water table variations that would have occurred in a large commercial plantation, by using the initial water table depth and lateral groundwater flow parameters obtained for a large nearby E. grandis stand growing on a similar soil type (Christina et al., 2017). Since measured structural and physiological tree parameters are inputs in the MAESPA model, there is no feedback between the predicted soil water balance and tree characteristics (e.g. LAI). Therefore, one potential issue comes from the prediction of groundwater uptake, as the real water table depth in the experiment may be different. We argue here that this bias leads to only limited errors in the predictions for several reasons.

(1) The water table depth was measured as $15 \mathrm{mps}$ to $17 \mathrm{mps}$ over the whole rotation in the experiment, which indicates that the trees did not have access to groundwater over the first 3 years after planting (unpublished data). This corresponds to our predictions for all treatments, since we predicted almost no groundwater uptake the first 3 years, and no water uptake below $14 \mathrm{mbs}$.

(2) In the fourth year, the predicted water table for all treatments except $-\mathrm{K}+\mathrm{W}$ reached depths similar to that measured in the experiment (17 mbs). For these treatments, we predicted groundwater uptake during that year, which was also probably occurring in the experiment.

(3) For $-\mathrm{K}+\mathrm{W}$, there was nearly no predicted groundwater uptake, even though the water table was predicted to be higher than in the other treatments. This lack of water uptake from the water table is therefore highly probable in the experimental plots where the water table was 6-8 $\mathrm{m}$ deeper than predicted for a large stand.

The quantification of the effects of $\mathrm{K}$ nutrition and water supply regimes on water storage in very deep soil layers as well as deep water seepage, which probably affects stream flows in catchment areas covered by eucalypt plantations, was among the most interesting outputs of our simulation approach.

\subsection{Consequences of different $K$ nutrition and water supply regimes on Eucalyptus water use and tree water stress}

In agreement with our first hypothesis, throughfall exclusion decreased tree water use and the groundwater recharge, increased tree water stress (shown by $\mathrm{I}_{\mathrm{Sws}}$ ) and increased the depth of water uptake in the soil. The soil-driven tree water stress index is an instantaneous index measuring the effect of soil water content on transpiration. Under a saturated soil, many tree traits should be impacted in turn due to plant plasticity (e.g. LAI), which was not the case in our simulation; therefore, the computed index act as an instantaneous water stress index considering only the direct effect of soil water content to stomatal conductance and plant transpiration. A decrease in groundwater recharge after planting, in response to a decrease in rainfall, led to a drop in the water table, through the continuous outgoing lateral groundwater flow within the catchment area. Management of eucalypt plantations has been shown to have a strong effect on the water table in Brazil with a rise from -26 mbs to -16 mbs after clear cutting (Almeida et al., 2007). In this experimental catchment area covered by highly productive plantations, the deep seepage over an entire rotation amounted to $3.6 \%$ of the total precipitation $\left(1147 \mathrm{~mm} \mathrm{yr}^{-1}\right.$ on average), which is consistent with our findings in K-fertilized plots. The contribution of soil water stored in deep soil layers is critical for tree survival in regions with frequent droughts. In Australia, Eucalyptus plantations with high stocking densities were highly sensitive to drought after 3 years of growth during dry periods (Harper et al., 2014). A strong relationship between tree growth rates (and mortality) and water table depth has been shown in groundwater-dependent ecosystems (Eamus et al., 2015), and in particular in Eucalyptus and Pinus forests (McGrath et al., 1991; Harper et al., 2009; Zolfaghar et al., 2015).

In agreement with our second hypothesis, a severe K-deficiency of $E$. grandis trees led to lower water use and lower tree water stress (shown by $\mathrm{I}_{\mathrm{sws}}$ ) in comparison with K-fertilized trees, and increased the groundwater recharge. A growing body of evidence suggests that forests 


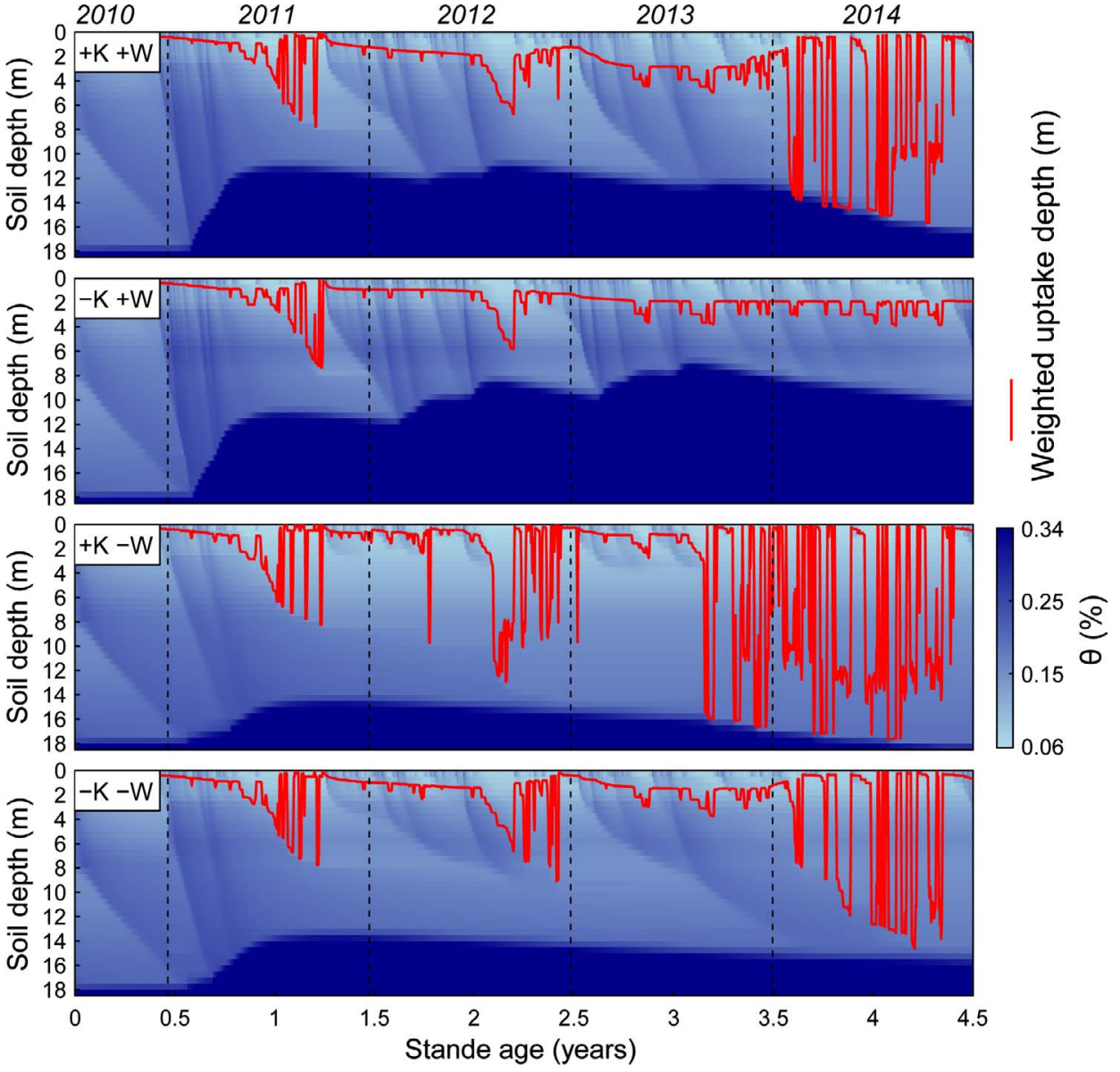

(a)

$$
\mathrm{T}_{\mathrm{C}}\left(\mathrm{mm} \mathrm{yr}^{-1}\right)
$$
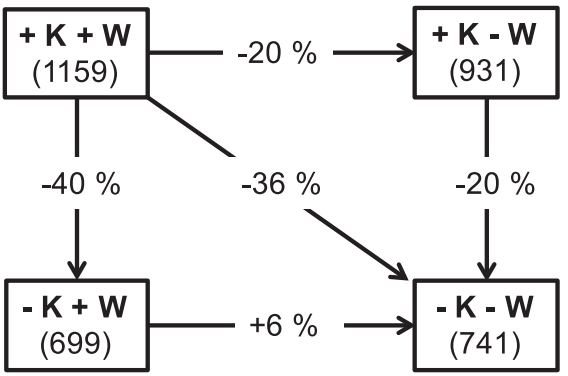

(c)

Amount of water stored in groundwater $\left(\mathrm{mm} \mathrm{yr}^{-1}\right)$

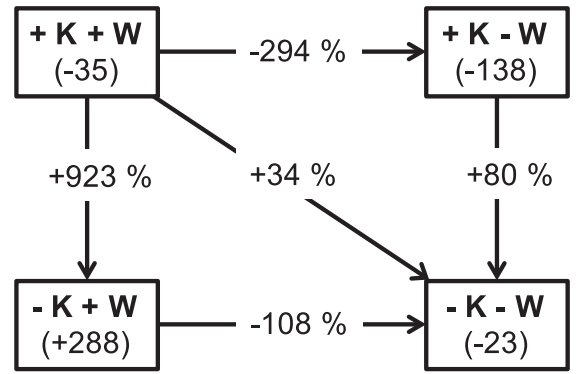

(b)

Soil water stress index, Isws,tot (unitless)

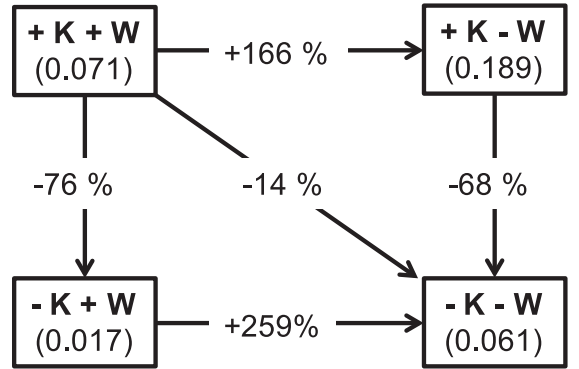

(d)

Deep seepage $\left(\mathrm{mm} \mathrm{yr}^{-1}\right)$

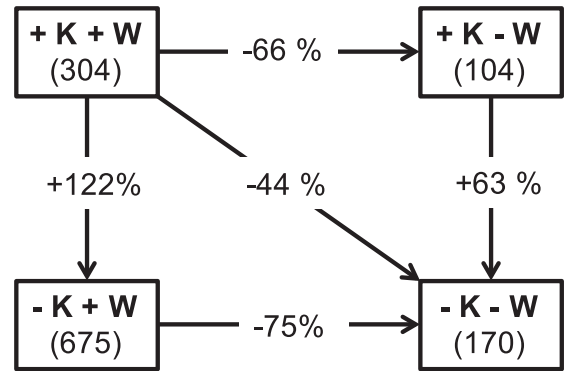

Fig. 4. Daily simulated soil water content $\left(\theta, \mathrm{m}^{3} \mathrm{~m}^{-3}\right)$ per soil layer down to $18 \mathrm{mbs}$ over the study period for undisturbed rainfall and $\mathrm{K}$ fertilization $(+\mathrm{K}+\mathrm{W})$ for potassium deficiency $(-\mathrm{K}+\mathrm{W})$, for throughfall exclusion $(+\mathrm{K}-\mathrm{W})$ and combined potassium deficiency and throughfall exclusion $(-\mathrm{K}-\mathrm{W})$. The red line indicates the daily weighted uptake depth (mbs).
Fig. 5. Mean responses of eucalypt trees to different potassium $(\mathrm{K})$ and water (W) supply regimes over the study period: (a) canopy tran-

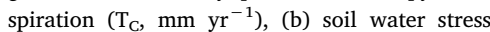
index ( $\mathrm{I}_{\mathrm{Sws}, \text { tot }}$, unitless), (c) changes in ground-

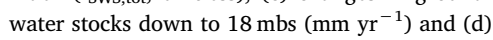
deep seepage (sum of lateral groundwater flow

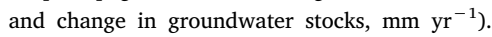
The variations are shown in percentages on arrows and mean annual values are indicated within each box. $-\mathrm{K}$ and $+\mathrm{K}$ are for the control and $\mathrm{K}$-supplied trees, respectively. $+\mathrm{W}$ and $-\mathrm{W}$ are for undisturbed rainfall and exclusion of $37 \%$ of throughfall, respectively. 
are less prone to water deficit under low than under high nutrient availability, as has been shown for Eucalyptus and Pinus plantations (Linder et al., 1987; Mendham et al., 2011; White et al., 2009; BattieLaclau et al., 2014a). Water stress and tree mortality in Eucalyptus plantations increased in response to nitrogen fertilization in Australia (Carter and White, 2009; Stoneman et al., 1997). An increase in tree water stress in response to $\mathrm{K}$ fertilization (this study), and $\mathrm{N}$ fertilization (White al., 2009; Mendham et al., 2011) might also occur for other nutrients, when a major deficiency in the soil is removed by fertilizer addition.

Despite the beneficial effect of nutrient supply on plant resistance to abiotic stresses (Cakmak, 2005; Reddy et al., 2004), our study emphasizes possible drawbacks of high fertilization on tree water stress over dry periods in fast-growing planted forests. Fertilization greatly increases leaf area and biomass production in Eucalyptus plantations (Leuning et al., 1991; Clearwater and Meinzer, 2001; Epron et al., 2012; Smethurst, 2010; du Toit et al., 2010), as well as photosynthetic activities in expanded leaves (Leuning et al., 1995; Battie-Laclau et al., 2014b, Forrester et al., 2013). High productivity in these fast-growing plantations is associated with high transpiration rates, which leads to reduced water storage in deep soil layers during rainy seasons (Christina et al., 2017) and might lead to an increase in tree water stress during the following dry periods.

Our results suggest that a reduced but adequate nutrient supply can help mitigate the adverse consequences of low precipitation on tree water stress and soil water resources. We compared highly fertilized trees with severe $\mathrm{K}$ deficiency in our study but intermediate $\mathrm{K}$ fertilizer addition should also be studied. Addition of sodium instead of potassium in the K-deficient soil of our study site led to water stress of $E$. grandis trees (shown by predawn leaf water potential) and wood production that was intermediate between K-fertilized trees and K-deficient trees (Battie-Laclau et al., 2014a).

\subsection{Managing water in eucalypt plantations under climate changes}

Tropical and subtropical planted forests provided $65 \%$ of the global wood consumption in 2012 (Payn et al., 2015). However, the intensity and duration of dry periods will probably increase in the future in many tropical and subtropical regions (Solomon et al., 2009). Therefore, management practices improving tree tolerance to severe drought are needed to satisfy a continuously increasing demand in wood (FAO, 2010). The partitioning between blue water and green water is a major issue in many regions (Farley et al., 2005; Jackson et al., 2005; Falkenmark and Rockström, 2006). While low evapotranspiration rates contribute to maintaining stream flows in afforested catchments, high evapotranspiration rates can positively affect the regional climate, though a decrease in land surface temperatures, and an increase in atmospheric humidity and precipitation (Bonan, 2008; Peng et al., 2014; Alkama et Cescatti, 2016; Syktus and McAlpine, 2016). Managing water in eucalypt plantations and, more generally, in agricultural lands is therefore essential to cope with both local and global issues.

Our study shows that soil depth is an essential criterion to consider for the selection of new afforestation sites in tropical regions prone to severe droughts. The depth of the soil explored by tree roots strongly influences the soil water storage capacity and the amount of water available for tree growth during dry periods (Harper et al., 2014, 2009; Laclau et al., 2013). Even though planting water-resistant genotypes is essential to limit the risks of tree mortality, the most resistant clones are not the most productive. When selecting the genotype to plant in each plot, forest managers must compromise between potential wood production and the risk of mortality during prolonged drought periods. Management practices leading to a reduction in stand transpiration by comparison with intensively managed plantations can contribute to increasing water storage in deep soil layers. Stand water use can be decreased through a reduction in LAI, which can be achieved by using stocking rates that are lower than the most productive plantations
(Mendham et al., 2011; Harper et al., 2014). However, tree plasticity leads to an increase in leaf area per tree when the stocking density decreases in Eucalyptus plantations (Le Maire et al., 2013; Stoneman et al., 1997), and a large decrease in the stocking density is therefore needed to substantially reduce LAI. Moreover, low stocking densities can have some drawbacks for Eucalyptus plantations (e.g. more difficult weed control, larger trunks to harvest,...) and other management options could be considered to improve the tolerance of tropical plantations to drought. Reducing the rotation period (i.e. the time between two successive harvests) could be another means of reducing tree water stress, with a more frequent groundwater recharge after clear cutting. For example, a rise of $6-10 \mathrm{~m}$ in the water table after clear cutting followed by a drop down to its initial depth has been observed in commercial eucalypt plantations intensively studied in two Brazilian states (Almeida et al., 2007; Christina et al., 2017). Thinning at mid rotation could also be an alternative to open the canopy and significantly reduce evapotranspiration and tree water stress in the last years before the final harvest (White et al., 2009).

Fertilization regimes can be a flexible tool to improve local tradeoffs between wood production and water resources. A reduction in fertilizer supply relative to current practices can strongly decrease stand water use and therefore contribute to enhancing the drought tolerance of the trees, but at the expense of stand productivity (White et al., 2009; Battie-Laclau et al., 2016, Christina et al., 2015). Fertilization regimes could be associated with other management practices (i.e. rotation periods, stocking densities, thinning at mid rotation, etc.) to limit the adverse consequences of severe droughts while maintaining a high wood production.

Major changes in management practices would be operationally challenging. High risks of tree mortality in a changing climate might require changes in the productivity objectives of tropical planted forests (Battie-Laclau et al. 2014a; Harper et al. 2014). The marked effect of drought on tree water uptake from deep soil layers in our study also suggests that management practices designed to reduce stand water use (and therefore stand productivity) might also be useful to maintain stream flows in some regions under a future drier climate.

\section{Conclusion}

Fertilization regimes strongly influence tree water use in intensively managed Eucalyptus plantations and can be used, with other management options, as a tool to decrease tree water stress through an increase in water storage in deep soil layers during rainy seasons. A decrease in annual rainfall increases the mean soil depth of water withdrawal, decreases the residual soil water content in deep soil layers and leads to a drop in the water table. The negative impact of a decrease in annual rainfall on soil water resources was lower for K-deficient trees than for $\mathrm{K}$-fertilized trees. Our study suggests that, in a context of climate change, current levels of nutrient supply in tropical planted forests might be revised to improve tree tolerance to severe droughts and to adjust the partitioning between blue water and green water to face both global and local issues.

\section{Acknowledgements}

The study was funded by Universidade de São Paulo, Centre de coopération Internationale en Recherche Agronomique pour le Développement (CIRAD), Agence Nationale de la Recherche (MACACC project ANR-13-AGRO-0005, Viabilité et Adaptation des Ecosystèmes Productifs, Territoires et Ressources face aux Changements Globaux AGROBIOSPHERE 2013 program),. This work has benefited from the support of Agropolis Foundation as part of the program "Investissements d'avenir" (ANR-10-LabX-0001-01) and from the support of the Brazilian state of 'Programa de Cooperacão internacional capes/Fundacão AGROPOLIS 017/2013'. The experimental site belongs to the SOERE F-ORE-T, which is supported annually by Ecofor, Allenvi 
and the French National Research Infrastructure ANAEE-F (http:// www.anaee-france.fr/fr/). We are grateful to the staff at the Itatinga Experimental Station, in particular Rildo Moreira e Moreira (Esalq, USP), as well as Eder Araujo da Silva (http://www.floragroapoio.com. br) for their technical support.

\section{Appendix A. Supplementary material}

Supplementary data associated with this article can be found, in the online version, at http://dx.doi.org/10.1016/j.foreco.2017.12.048.

\section{References}

Alkama, R., Cescatti, A., 2016. Biophysical climate impacts of recent changes in global forest cover. Science 351, 600-604.

Allen, C.D., 2009. Climate-induced forest dieback: an escalating global phenomenon? Unasylva 60, 231-232.

Allison, I., Bindoff, N.L., Bindschadler, R.A., Cox, P.M., de Noblet, N., England, M.H., Francis, J.E., Gruber, N., Haywood, A.M., Karoly, D.J., Kaser, G., Le Quere, C., Lenton, T.M., Mann, M.E., McNeil, B.I., Pitman, A.J., Rahmstorf, S., Rignot, E., Schellnhuber, H.J., Schneider, S.H., Sherwood, S.C., Somerville, R.C.J., Steffen, K., Steig, E.J., Visbeck, M., Weaver, A.J., 2009. The Copenhagen Diagnosis: Updating the World on the Latest Climate Science.

Almeida, A.C., Soares, J.V., Landsberg, J.J., Rezende, G.D., 2007. Growth and water balance of Eucalyptus grandis hybrid plantations in Brazil during a rotation for pulp production. For. Ecol. Manage. 251, 10-21.

Almeida, A.C., Siggins, A., Batista, T.R., Beadle, C., Fonseca, S., Loos, R., 2010. Mapping the effect of spatial and temporal variation in climate and soils on Eucalyptus plantation production with 3-PG, a process-based growth model. For. Ecol. Manage. 259, 1730-1740.

Battie-Laclau, P., Laclau, J.-P., Domec, J.-C., Christina, M., Bouillet, J.-P., de Cassia Piccolo, M., de Moraes Gonçalves, J.L., Moreira, R.M.E., Krusche, A.V., Bouvet, J.-M., Nouvellon, Y., 2014a. Effects of potassium and sodium supply on drought-adaptive mechanisms in Eucalyptus grandis plantations. New Phytol. 203, 401-413.

Battie-Laclau, P., Laclau, J.-P., Beri, C., Mietton, L., Muniz, M.R.A., Arenque, B.C., Piccolo, M.C., Jordan-Meille, L., Bouillet, J.-P., Nouvellon, Y., 2014b. Photosynthetic and anatomical responses of Eucalyptus grandis leaves to potassium and sodium supply in a field experiment. Plant, Cell Environ. 37, 70-81.

Battie-Laclau, P., Delgado-Rojas, J.S., Christina, M., Nouvellon, Y., Bouillet, J.-P., Piccolo, M.C., Moreira, M.Z., Gonçalves, J.L.M., Roupsard, O., Laclau, J.-P., 2016. Potassium fertilization increases water-use efficiency for stem biomass production without affecting intrinsic water-use efficiency in Eucalyptus grandis plantations. For. Ecol. Manage. 364, 77-89.

Bonan, G.B., 2008. Forests and climate change: forcings, feedbacks, and the climate benefits of forests. Science 320, 1444-1449.

Brouwers, N., Matusick, G., Ruthrof, K., Lyons, T., Hardy, G., 2013. Landscape-scale assessment of tree crown dieback following extreme drought and heat in a Mediterranean eucalypt forest ecosystem. Landscape Ecol. 28, 69-80.

Cakmak, I., 2005. The role of potassium in alleviating detrimental effects of abiotic stresses in plants. J. Plant Nutr. Soil Sci. 168, 521-530.

Carter, J.L., White, D.A., 2009. Plasticity in the Huber value contributes to homeostasis in leaf water relations of a mallee Eucalypt with variation to groundwater depth. Tree Physiol. 29, 1407-1418.

Christina, M., Laclau, J.P., Gonçalves, J.L.M., Jourdan, C., Nouvellon, Y., Bouillet, J.P., 2011. Almost symmetrical vertical growth rates above and below ground in one of the world's most productive forests. Ecosphere 2, 1-10.

Christina, M., Maire, G. Le, Battie-Laclau, P., Nouvellon, Y., Bouillet, J.-P., Jourdan, C., de Moraes Gonçalves, J.L., Laclau, J.-P., 2015. Measured and modeled interactive effects of potassium deficiency and water deficit on gross primary productivity and light use efficiency in Eucalyptus grandis plantations. Glob. Chang. Biol. 21, 2022-2039.

Christina, M., Nouvellon, Y., Laclau, J.-P., Stape, J.L., Bouillet, J.-P., Lambais, G.R., le Maire, G., 2017. Importance of deep water uptake in tropical eucalypt forest. Funct. Ecol. 31, 509-519.

Clearwater, M.J., Meinzer, F.C., 2001. Relationships between hydraulic architecture and leaf photosynthetic capacity in nitrogen-fertilized Eucalyptus grandis trees. Tree Physiol. 21, 683-690.

Cossalter, C., Pye-Smith, C., 2003. Fast-wood Forestry: Myths and Realities. CIFOR, Bogor, Indonesia.

da Costa, A.C.L., Galbraith, D., Almeida, S., Portela, B.T.T., da Costa, M., Silva, J.D., Braga, A.P., de Goncalves, P.H.L., de Oliveira, A.A.R., Fisher, R., Phillips, O.L., Metcalfe, D.B., Levy, P., Meir, P., 2010. Effect of 7 yr of experimental drought on vegetation dynamics and biomass storage of an eastern Amazonian rainforest. New Phytol. 187, 579-591.

Dawson, T.E., Pate, J.S., 1996. Seasonal water uptake and movement in root systems of Australian phraeatophytic plants of dimorphic root morphology: a stable isotope investigation. Oecologia 107, 13-20.

Delgado-Rojas, J.S., Laclau, J., Roupsard, O., Stape, J., Ranger, J., Bouillet, J., Nouvellon, Y., 2010. Calibration of Home-made Heat Dissipation Probes for a Full Rotation of Eucalyptus grandis Trees in Brazil. American Geophysical Union, San Francisco.

Dutkowski, G.W., Potts, B.M., 2012. Genetic variation in the susceptibility of Eucalyptus globulus to drought damage. Tree Genet. Genomes 8, 757-773.

Duursma, R.A., Medlyn, B.E., 2012. MAESPA: a model to study interactions between water limitation, environmental drivers and vegetation function at tree and stand levels, with an example application to $\left[\mathrm{CO}_{2}\right] \times$ drought interactions. Geosci. Model Dev. 5, 919-940.

Eamus, D., Zolfaghar, S., Villalobos-Vega, R., Cleverly, J., Huete, A., 2015. Groundwaterdependent ecosystems: recent insights from satellite and field-based studies. Hydrol. Earth Syst. Sci. 19, 4229-4256.

Epron, D., Laclau, J.P., Almeida, J.C.R., Gonalves, J.L.M., Ponton, S., Sette, C.R., DelgadoRojas, J.S., Bouillet, J.P., Nouvellon, Y., 2012. Do changes in carbon allocation account for the growth response to potassium and sodium applications in tropical Eucalyptus plantations? Tree Physiol. 32, 667-679.

Falkenmark, M., Rockström, J., 2006. The new blue and green water paradigm: breaking new ground for water resources planning and management. J. Water Resour. Plann. Manage. 132, 129-132.

FAO, 2010. Global forest resources assessment. Rome, Italy.

Farley, K.A., Jobbágy, E.G., Jackson, R.B., 2005. Effects of afforestation on water yield: A global synthesis with implications for policy. Glob. Chang. Biol. 11, 1565-1576.

Forrester, D.I., Collopy, J.J., Beadle, C.L., Baker, T.G., 2013. Effect of thinning, pruning and nitrogen fertiliser application on light interception and light-use efficiency in a young Eucalyptus nitens plantation. For. Ecol. Manage. 288, 21-30.

Harper, R.J., Smettem, K.R.J., Carter, J.O., McGrath, J.F., 2009. Drought deaths in Eucalyptus globulus (Labill.) plantations in relation to soils, geomorphology and climate. Plant Soil 324, 199-207.

Harper, R.J., Sochacki, S.J., Smettem, K.R.J., Robinson, N., 2014. Managing water in agricultural landscapes with short-rotation biomass plantations. GCB Bioenergy 6 , 544-555.

IPCC, 2013. Summary for policymakers. in: Stocker, T., Qin, D., Plattner, G., Tignor, M., Allen, S., Boschung, J., Nauels, A., Xia, Y., Bex, V., Midgley, P. (Eds.), Climate Change 2013: The Physical Science Basis. Contribution of Working Group I to the Fifth Assessment Report of the Intergovernmental Panel on Climate Change. Cambridge, pp. 1-30.

Jackson, P.C., Meinzer, F.C., Bustamante, M., Goldstein, G., Franco, A., Rundel, P.W., Caldas, L., Igler, E., Causin, F., 1999. Partitioning of soil water among tree species in a Brazilian Cerrado ecosystem. Tree Physiol. 19, 717-724.

Jackson, R.B., Jobbágy, E.G., Avissar, R., Roy, S.B., Barrett, D.J., Cook, C.W., Farley, K.A., le Maitre, D.C., McCarl, B.A., Murray, B.C., 2005. Trading water for carbon with biological carbon sequestration. Science 310, 1944-1947.

Köstner, B., Granier, A., Cermák, J., 1998. Sapflow measurements in forest stands: methods and uncertainties. Ann. des Sci. For. 55, 13-27.

Laclau, J.-P., Almeida, J.C.R., Gonçalves, J.L.M., Saint-André, L., Ventura, M., Ranger, J., Moreira, R.M., Nouvellon, Y., 2009. Influence of nitrogen and potassium fertilization on leaf lifespan and allocation of above-ground growth in Eucalyptus plantations. Tree Physiol. 29, 111-124.

Laclau, J.P., Ranger, J., de Moraes Gonçalves, J.L., Maquère, V., Krusche, A.V., M'Bou, A.T., Nouvellon, Y., Saint-André, L., Bouillet, J.P., de Cassia Piccolo, M., Deleporte, P., 2010. Biogeochemical cycles of nutrients in tropical Eucalyptus plantations. Main features shown by intensive monitoring in Congo and Brazil. For. Ecol. Manage. 259, 1771-1785.

Laclau, J.-P., da Silva, E.A., Rodrigues Lambais, G., Bernoux, M., le Maire, G., Stape, J.L., Bouillet, J.-P., Gonçalves, J.L. de M., Jourdan, C., Nouvellon, Y., 2013. Dynamics of soil exploration by fine roots down to a depth of $10 \mathrm{~m}$ throughout the entire rotation in Eucalyptus grandis plantations. Front. Plant Sci. 4, 1-12.

Leuning, R., Kelliher, F.M., Pury, D.G.G., Schulze, E.D., 1995. Leaf nitrogen, photosynthesis, conductance and transpiration: scaling from leaves to canopies. Plant, Cell Environ. 18, 1183-1200.

Leuning, R., Kriedemann, P.E., McMurtrie, R.E., 1991. Simulation of evapotranspiration by trees. Agric. Water Manage 19, 205-221.

Linder, S., Benson, M.L., Myers, B.J., Raison, R.J., 1987. Canopy dynamics and growth of Pinus radiata: I. Effects of irrigation and fertilization during a drought. Can. J. Forest Res. 17, 1157-1165.

Litton, C.M., Raich, J.W., Ryan, M.G., 2007. Carbon allocation in forest ecosystems. Glob. Chang. Biol. 13, 2089-2109.

le Maire, G., Marsden, C., Verhoef, W., Ponzoni, F.J., Lo Seen, D., Bégué, A., Stape, J.L., Nouvellon, Y., 2011. Leaf area index estimation with MODIS reflectance time series and model inversion during full rotations of Eucalyptus plantations. Remote Sens. Environ. 115, 586-599.

le Maire, G., Nouvellon, Y., Christina, M., Ponzoni, F.J., Gonçalves, J.L.M., Bouillet, J.P., Laclau, J.P., 2013. Tree and stand light use efficiencies over a full rotation of singleand mixed-species Eucalyptus grandis and Acacia mangium plantations. For. Ecol. Manage. 288, 31-42.

Malhi, Y., Roberts, J.T., Betts, R.A., Killeen, T.J., Li, W., Nobre, C.A., 2008. Climate change, deforestation, and the fate of the Amazon. Science 319, 169-172.

Malhi, Y., Aragão, L.E.O.C., Galbraith, D., Huntingford, C., Fisher, R., Zelazowski, P., Sitch, S., McSweeney, C., Meir, P., 2009. Exploring the likelihood and mechanism of a climate-change-induced dieback of the Amazon rainforest. Proc. Natl. Acad. Sci. U. S. A. 106, 20610-20615.

Markewitz, D., Devine, S., Davidson, E.A., Brando, P., Nepstad, D.C., 2010. Soil moisture depletion under simulated drought in the Amazon: impacts on deep root uptake. New Phytol. 187, 592-607.

McGrath, J.F., Ward, D., Jenkins, P.J., Read, B., 1991. Influence of site factors on the productivity and drought susceptibility of Pinus radiata in the Blackwood Valley Region of Western Australia. in: Productivity in Perspective. Third Australia Forest Soils and Nutrition Conference. Sydney, Melbourne, pp. 65-66.

Medlyn, B.E., 1998. Physiological basis of the light use efficiency model. Tree Physiol. 18, $167-176$.

Medlyn, B.E., Pepper, D.A., O'Grady, A.P., Keith, H., 2007. Linking leaf and tree water use with an individual-tree model. Tree Physiol. 27, 1687-1699. 
Mendham, D., White, D., Battaglia, M., McGrath, J., Short, T., Ogden, G., Kinal, J., 2011. Soil water depletion and replenishment during first- and early second-rotation Eucalyptus globulus plantations with deep soil profiles. Agric. For. Meteorol. 151, 1568-1579.

Nepstad, D.C., Decarvalho, C.R., Davidson, E.A., Jipp, P.H., Lefebvre, P.A., Negreiros, G.H., Dasilva, E.D., Stone, T.A., Trumbore, S.E., Vieira, S., 1994. The role of deep roots in the hydrological and carbon cycles of amazonian forests and pastures. Nature 372, 666-669.

Oliveira, R.S., Bezerra, L., Davidson, E.A., Pinto, F., Klink, C.A., Nepstad, D.C., Moreira, A., 2005. Deep root function in soil water dynamics in cerrado savannas of central Brazil. Funct. Ecol. 19, 574-581.

Paquette, A., Messier, C., 2010. The role of plantations in managing the world's forests in the Anthropocene. Front. Ecol. Environ. 8, 27-34.

Payn, T., Carnus, J.M., Freer-Smith, P., Kimberley, M., Kollert, W., Liu, S., Orazio, C., Rodriguez, L., Silva, L.N., Wingfield, M.J., 2015. Changes in planted forests and future global implications. For. Ecol. Manage. 352, 57-67.

Peng, S.-S., Piao, S., Zeng, Z., Ciais, P., Zhou, L., Li, L.Z.X., Myneni, R.B., Yin, Y., Zeng, H., 2014. Afforestation in China cools local land surface temperature. Proc. Natl. Acad. Sci. U. S. A. 111, 2915-2919.

Reddy, A.R., Chaitanya, K.V., Vivekanandan, M., 2004. Drought-induced responses of photosynthesis and antioxidant metabolism in higher plants. J. Plant Physiol. 161, 1189-1202.

Rojas, P.V., Ipinza, R.C., Gutierrez, B., Molina, M.P., Arnold, R.J., Ipinza, R.C., Gutierrez, B., Molina, M.P., Arnold, R.J., 2017. Breeding eucalyptus globulus for lower rainfall sites in the Bío-Bío Region of Chile breeding eucalyptus globulus for lower rainfall sites in the Bío-Bío Region of Chile. Aust. Forestry 80, 105-112.

Smethurst, P.J., 2010. Forest fertilization: Trends in knowledge and practice compared to agriculture. Plant Soil 335, 83-100.

Solomon, S., Plattner, G.-K., Knutti, R., Friedlingstein, P., 2009. Irreversible climate change due to carbon dioxide emissions. Proc. Natl. Acad. Sci. U. S. A. 106, 1704-1709.

Stoneman, G.L., Crombie, D.S., Whitford, K., Hingston, F.J., Giles, R., Portlock, C.C.,
Galbraith, J.H., Dimmock, G.M., 1997. Growth and water relations of Eucalyptus marginata (jarrah) stands in response to thinning and fertilization. Tree Physiol. 17, 267-274.

Syktus, J.I., McAlpine, C.A., 2016. More than carbon sequestration: Biophysical climate benefits of restored savanna woodlands. Sci. Rep. 6, 29194.

du Toit, B., Smith, C.W., Little, K.M., Boreham, G., Pallett, R.N., 2010. Intensive, sitespecific silviculture: Manipulating resource availability at establishment for improved stand productivity. A review of South African research. For. Ecol. Manage. 259, 1836-1845.

Tuzet, A., Perrier, A., Leuning, R., 2003. A coupled model of stomatal conductance, photosynthesis and transpiration. Plant, Cell Environ. 26, 1097-1116.

Wang, Y.P., Jarvis, P.G., 1990. Description and validation of an array model-MAESTRO. Agric. For. Meteorol. 51, 257-280.

White, D.A., Crombie, D.S., Kinal, J., Battaglia, M., McGrath, J.F., Mendharn, D.S., Walker, S.N., 2009. Managing productivity and drought risk in Eucalyptus globulus plantations in south-western Australia. For. Ecol. Manage. 259, 33-44.

White, D.A., McGrath, J.F., Ryan, M.G., Battaglia, M., Mendham, D.S., Kinal, J., Downes, G.M., Crombie, D.S., Hunt, M.E., 2014. Managing for water-use efficient wood production in Eucalyptus globulus plantations. For. Ecol. Manage. 331, 272-280.

Williams, M., Bond, B.J., Ryan, M.G., 2001a. Evaluating different soil and plant hydraulic constraints on tree function using a model and sap flow data from ponderosa pine. Plant, Cell Environ. 24, 679-690.

Williams, M., Law, B.E., Anthoni, P.M., Unsworth, M.H., 2001b. Use of a simulation model and ecosystem flux data to examine carbon-water interactions in ponderosa pine. Tree Physiol. 21, 287-298.

Zolfaghar, S., Villalobos-Vega, R., Cleverly, J., Zeppel, M., Rumman, R., Eamus, D., 2014 The influence of depth-to-groundwater on structure and productivity of Eucalyptus woodlands. Aust. J. Bot. 62, 428-437.

Zolfaghar, S., Villalobos-Vega, R., Zeppel, M., Eamus, D., 2015. The hydraulic architecture of Eucalyptus trees growing across a gradient of depth-to-groundwater. Funct. Plant Biol. A 42, 888-898. 